\title{
EFFECTS OF SLURRY AND SOIL CONDITIONERS ON THE YIELD, PROTEIN AND ASH CONTENT IN ITALIAN RYEGRASS (LOLIUM MULTIFLORUM LAM)
}

\author{
WIŚNIEWSKA-KADŻAJAN, B. ${ }^{*}$ - JANKOWSKI, K. \\ Institute of Agriculture and Horticulture, University of Natural Sciences and Humanities in \\ Siedlce, B. Prusa 14, 08-110 Siedlce, Poland \\ (phone: +48-25-643-1320) \\ *Corresponding author \\ e-mail: beata.wisniewska-kadzajan@uph.edu.pl \\ (Received $17^{\text {th }}$ Oct 2019; accepted $23^{\text {rd }}$ Jan 2020)
}

\begin{abstract}
The purpose of this research was to determine the effect of slurry applied on its own and supplemented with mineral fertilizers or soil conditioners (UGmax and Humus Active) on the yield of Lolium multiflorum and on its total protein and crude ash contents. The research was conducted on the basis of a two-year (2016-2017) field experiment in which Lolium multiflorum forage grass of the Dukat variety was used. For the two growing seasons the highest average yield of the grass was obtained from plots with slurry application and mineral fertilizers. However, interaction of slurry with soil conditioners resulted in a lower yield compared to the plot where slurry was used on its own. The highest total protein content was obtained to Lolium multiflorum treated with slurry supplemented with mineral fertilizers. The highest crude ash content (an average across growing seasons and treatments) was recorded in the biomass of the third harvest, with the lowest amount recorded in the first.
\end{abstract}

Keywords: fertilization, feed value, forage grasses

\section{Introduction}

The primary nutrient that determines forage quality is protein. According to Brzóska and Śliwiński (2011) total protein is made up of true protein and non-protein nitrogen compounds. Kukułka and Kozłowski (2004) point out that the share of true protein in grass biomass is $80-95 \%$ of total protein, while non-protein nitrogen compounds constitute the other $5-20 \%$. The content of this nutrient in forage is affected to the highest degree by the level of nitrogen fertiliser. However, the amount of nitrogen doses mainly increases the content of non-protein nitrogen in plants. For this reason, with intensive nitrogen application the share of true protein might be reduced by up to $50-60 \%$.

According to Falkowski et al. (2000), total protein content in grass also depends on the species and even on the variety, habitat fertility with the level of nitrogen, the development stage of the plant, the weather, and the harvest.

In addition to total protein, crude ash content is equally important from the point deleted of plant nutritional value (Kitczak et al., 2011). Forage mineral content is dependent on the species composition, the stage of plant development during harvest, and on weather conditions. Chemical elements required by animals in large quantities are potassium, phosphorus, magnesium, and calcium. Equally important but absorbed in small quantities are microelement such as copper, zinc, or manganese (Falkowski et al., 2000). 
The research was aimed at assessing the yield of Lolium multiforum biomass, as well as the content of total protein and crude ash as a result of slurry applied on its own and supplemented with soil conditioners or NPK mineral fertilisers.

Supplementing the slurry with biopreparations was supposed to show how it will affect the amount of biomass obtained as well as the content of protein and ash components in it. In addition, the experiment was to assess whether the addition of biological preparations to liquid manure is able to balance complementary mineral fertilization.

\section{Materials and methods}

The research was carried out on the basis of a two-year (2016-2017) field experiment established at the experimental facility of the University of Natural and Sciences and Humanities in Siedlce, with three replications and random layouts. The area of an experimental plot was $4.5 \mathrm{~m}^{2}(1.5 \times 3.0 \mathrm{~m})$.

The main experimental factor tested in the research was slurry used separately and supplemented with NPK mineral fertilizers or soil conditioners with the commercial names of UGmax and Humus Active. The following research units were set up: (1) control (no treatment); (2) slurry; (3) slurry + UGmax; (4) slurry + Humus Active; (5) slurry + NPK.

The effect of slurry, soil conditioners, and mineral fertilisers was tested on the forage grass of the Lolium multiflorum species of the Dukat variety. It was sown in autumn 2015 at the sowing standard of $18 \mathrm{~kg} \mathrm{ha}^{-1}$. Slurry from dairy cows was used as natural fertiliser. It was applied each year in a total dose of $30 \mathrm{~m}^{3} \mathrm{ha}^{-1}$ divided into three equal parts used before each growth cycle.

Slurry had dry matter concentration of $10 \%$, with a narrow ratio of $\mathrm{C}: \mathrm{N}(8: 1)$, while the concentration of selected macronutrients was as follows $\left(\mathrm{g} \mathrm{kg}^{-1} \mathrm{DM}\right): \mathrm{N}-33.0, \mathrm{P}_{2} \mathrm{O}_{5}$ 16.0, $\mathrm{K}_{2} \mathrm{O}-16, \mathrm{MgO}-10.0$ and $\mathrm{Ca}-21.0$. Soil conditioners, according to the Institute of Soil Science and Plant Cultivation in Puławy, Poland, improve soil properties. Their composition is shown in Table 1.

Table 1. Composition of soil conditioners

\begin{tabular}{c|c|c|c|c|c|c|c|c|c|c|c}
\hline \multirow{2}{*}{$\begin{array}{c}\text { Soil } \\
\text { conditioner }\end{array}$} & \multicolumn{5}{|c|}{$\begin{array}{c}\text { Macronutrients } \\
\left(\mathbf{g ~ k g}^{-1}\right)\end{array}$} & \multicolumn{4}{c|}{$\begin{array}{c}\text { Micronutrients } \\
\left(\mathbf{m g ~ k g}^{-1}\right)\end{array}$} & \multirow{2}{*}{ Microorganism and others } \\
\cline { 2 - 8 } & $\mathbf{N}$ & $\mathbf{P}$ & $\mathbf{K}$ & $\mathbf{C a}$ & $\mathbf{M g}$ & $\mathbf{N a}$ & $\mathbf{M n}$ & $\mathbf{F e}$ & $\mathbf{Z n}$ & $\mathbf{C u}$ & \\
\hline UGmax & 1.2 & 0.2 & 2.9 & - & 0.1 & 0.2 & 0.3 & - & - & - & $\begin{array}{c}\text { Lactic acid bacteria, } \\
\text { photosynthetic bacteria, } \\
\text { Azotobacter, Pseudomonas, } \\
\text { yeast, actinomycetes }\end{array}$ \\
\hline $\begin{array}{c}\text { Humus } \\
\text { Active }\end{array}$ & 0.2 & 1.3 & 4.6 & 3.0 & 0.5 & - & 15 & 500 & 3 & 1 & $\begin{array}{c}\text { Permanent active humus with } \\
\text { beneficial microorganisms }\end{array}$ \\
\hline
\end{tabular}

Soil conditioners were used annually before the first growth cycle at doses recommended by the manufacturer, i.e. UGmax (Ecodarpol company) at $0.6 \mathrm{~L} \mathrm{ha}^{-1}$ and Humus Active (Bogdan company) at $50 \mathrm{~L} \mathrm{ha}^{-1}$. The addition of biologicals slurry was supposed to increase the use of manure nutrients by reducing losses, especially nitrogen. In addition, both biopreparations alleviate the symptoms of drought. Mineral nitrogen- 
phosphate-potassium fertilisers (NPK) were used in the following doses: $\mathrm{N}-100, \mathrm{P}$ $\left(\mathrm{P}_{2} \mathrm{O}_{5}\right)-80, \mathrm{~K}\left(\mathrm{~K}_{2} \mathrm{O}\right)-120 \mathrm{~kg} \mathrm{ha}^{-1}$. Mineral nitrogen fertilizers were used in the form of ammonium nitrate $\left(\mathrm{NH}_{4} \mathrm{NO}_{3}\right)$, phosphorus in the form of triple granular superphosphate $\left(\mathrm{Ca}\left(\mathrm{H}_{2} \mathrm{PO}_{4}\right)_{2}\right)$ and potassium in the form of potassium salt $(\mathrm{KCl})$. Phosphorus was applied once a year before the first growth cycle, whereas nitrogen and potassium doses were divided into three equal parts: the first before the start of vegetation, the second and third before the second and third growth cycles.

The experiment was set up on the soil with granulometric composition of loamy sand, the order of anthropogenic soils, the type of culture earth soil, and the subtype of hortisole (Polish Soil Classification, 2011). Chemical analysis of the soil found that carbon concentration in organic compounds $\left(C_{\text {org }}\right)$ was $14.50 \mathrm{~g} \mathrm{~kg}^{-1} \mathrm{DM}$, with total nitrogen of $1.36 \mathrm{~g} \mathrm{~kg}^{-1} \mathrm{DM}$. The ratio of $\mathrm{C}: \mathrm{N}$ was $10.6: 1$, and the $\mathrm{pH}$ value was 6.7 . The concentration of absorbable forms of phosphorus (170.00 mg kg-1 DM) and magnesium $\left(84.00 \mathrm{mg} \mathrm{kg}^{-1} \mathrm{DM}\right)$ was high, with moderate concentration of potassium $(114.00 \mathrm{mg}$ $\left.\mathrm{kg}^{-1} \mathrm{DM}\right)$.

Hydrothermal conditions were determined on the basis of meteorological data from the Hydrological and Meteorological Station in Siedlce. In order to measure temporal variability of weather conditions and their effects on plant growth and development Sielianinov's hydrothermal coefficient (Table 2) was determined (Bac et al., 1993). It was calculated using the monthly sum of atmospheric precipitation $(\mathrm{P})$ and the monthly sum of average daily air temperatures $(\Sigma \mathrm{t})$, applying the formula: $\mathrm{K}=\mathrm{P} / 0.1 \Sigma \mathrm{t}$ (Skowera and Puła, 2004).

Table 2. The value of Sielianinov's hydrothermal coefficient $(K)$ in the growing seasons

\begin{tabular}{c|c|c|c|c|c|c|c}
\hline \multirow{2}{*}{ Year } & \multicolumn{7}{|c}{ Month } \\
\cline { 2 - 8 } & April & May & June & July & August & September & October \\
\hline 2015 & 1.36 & 1.87 & 1.64 & 0.59 & 1.92 & 0.64 & 0.12 \\
2016 & 1.22 & 2.63 & 0.87 & 1.08 & 0.18 & 1.46 & 1.94 \\
2017 & 2.88 & 1.15 & 1.08 & 0.45 & 0.96 & 1.92 & 1.90 \\
\hline
\end{tabular}

$\mathrm{K} \leq 0.4$ extremely dry (ed), $0.4<\mathrm{K} \leq 0.7$ severely dry (sd), $0.7<\mathrm{K} \leq 1.0$ dry (d), $1.0<\mathrm{K} \leq 1.3$ moderately dry (md), $1.3<\mathrm{K} \leq 1.6$ optimal (o), $1.6<\mathrm{K} \leq 2.0$ moderately wet (mw), $2.0<\mathrm{K} \leq 2.5$ wet (w), $2.5<\mathrm{K} \leq 3.0$ severely wet (sw), $\mathrm{K}>3.0$ extremely wet (ew)

The optimal value of this coefficient was the range of $1.3<\mathrm{K} \leq 1.6$ (Skowera and Puła, 2004). In the first year (2016) the optimum thermal and humidity conditions occurred only in the month of September, with severely wet May, while June, July, and August, the most important months for plant growth and development of plants, were dry, moderately dry, and extremely dry. In the second year of the experiment the period from May to August ranged from moderately dry to severely dry, and the optimum conditions were not recorded during any month of the growing season.

During the two-year experiment in each growing season three harvests of grass were collected. Immediately after each harvest fresh matter was weighed, and a sample of 0.5 $\mathrm{kg}$ was collected to determine the yield of dry matter and to perform chemical analyses. The yield of dry matter was determined with the drying method. Total protein and crude ash content was measured with the near-infrared spectroscopy method (LSDS), using the LSDFlex N-500 with the ready-to-use INGOT calibration for dry forage. The 
method is described in detail in the Polish standard of PN-EN ISO 12099:2010 and in the literature (Burns et al., 2010; Reddersen et al., 2012).

Analysis of variance for a three-factor experiment was used to process the results statistically. The significance of the effect of various treatments on the value of the tested traits was checked with the Fisher-Snedecor F test. The statistical program of Statistica 6.0-2001 was used for calculations.

\section{Results}

Dry matter yields (Table 3) of Lolium multiflorum showed a significant variation depending on the treatment applied and the harvest. In the first and second year the highest yield, 12,40 and $12.90 \mathrm{Mg} \mathrm{ha}^{-1}$, respectively, was obtained from the plot where slurry was supplemented with NPK fertilisers. The lowest biomass yield was on the control plot (8.70 in the first and $9.50 \mathrm{Mg} \mathrm{ha}^{-1}$ in the second year.

In the first and second year the highest yield, 12,40 and $12.90 \mathrm{Mg} \mathrm{ha}^{-1}$, respectively, was obtained from the plot where slurry was supplemented with NPK fertilisers. The lowest biomass yield was on the control plot $\left(8.70\right.$ in the first and $9.50 \mathrm{Mg} \mathrm{ha}^{-1}$ in the second year. The addition of soil conditioners to slurry did not significantly increase the biomass of the grass compared with plots treated with slurry only. In the first year of the research the biomass yield on the plot treated with slurry and the Humus Active soil conditioner was lower than on the plot with slurry applied on its own. In the second year, plants responded with a lower yield to both of the soil conditioners added to slurry.

Table 3. Dry matter yield of Lolium multiflorum $\left(\mathrm{Mg} \mathrm{ha}^{-1}\right)$

\begin{tabular}{|c|c|c|c|c|c|c|c|}
\hline \multirow{2}{*}{$\begin{array}{l}\text { Growing } \\
\text { season } \\
\text { (B) }\end{array}$} & \multirow{2}{*}{$\begin{array}{l}\text { Harvest } \\
\text { (C) }\end{array}$} & \multicolumn{5}{|c|}{ Treatments (A) } & \multirow{2}{*}{ Means } \\
\hline & & $\mathbf{O}$ & $\mathbf{S}$ & S + UGmax & $\mathbf{S}+\mathbf{H A}$ & $S+N P K$ & \\
\hline \multirow{4}{*}{2016} & I & 3.10 & 4.20 & 4.30 & 4.10 & 4.50 & 4.04 \\
\hline & II & 2.90 & 3.50 & 3.50 & 3.80 & 4.40 & 3.62 \\
\hline & III & 2.70 & 3.80 & 4.00 & 2.30 & 3.50 & 3.26 \\
\hline & Total & 8.70 & 11.50 & 11.80 & 10.20 & 12.40 & 10.9 \\
\hline \multirow{4}{*}{2017} & $\mathrm{I}$ & 3.60 & 4.50 & 4.30 & 4.40 & 4.70 & 4.30 \\
\hline & II & 3.10 & 3.50 & 3.80 & 4.00 & 4.20 & 3.72 \\
\hline & III & 2.80 & 4.30 & 2.40 & 2.60 & 4.00 & 3.22 \\
\hline & Total & 9.50 & 12.30 & 10.50 & 11.00 & 12.90 & 11.24 \\
\hline \multicolumn{2}{|c|}{$\begin{array}{c}\text { Means across growing } \\
\text { seasons }\end{array}$} & 9.10 & 11.90 & 11.15 & 10.60 & 12.65 & 11.07 \\
\hline \multicolumn{8}{|c|}{ Means across harvests } \\
\hline \multicolumn{2}{|c|}{ I } & 3.35 & 4.35 & 4.30 & 4.25 & 4.66 & 4.17 \\
\hline \multicolumn{2}{|c|}{ II } & 3.00 & 3.50 & 3.65 & 3.90 & 4.30 & 3.67 \\
\hline \multicolumn{2}{|c|}{ III } & 2.75 & 4.05 & 3.20 & 2.45 & 3.75 & 3.24 \\
\hline $\mathrm{LSD}_{0.05}$ for: & $\begin{array}{l}\mathrm{A}=0.7 \\
\mathrm{~A} / \mathrm{B}=\mathrm{N} \\
\mathrm{C} / \mathrm{A}=\mathrm{N}\end{array}$ & & $\begin{array}{l}\text { NS } \\
=\text { NS } \\
=\text { NS }\end{array}$ & $\begin{array}{l}\mathrm{C}=0.49 \\
\mathrm{~A} / \mathrm{C}=\mathrm{NS} \\
\mathrm{C} / \mathrm{B}=\mathrm{NS}\end{array}$ & & & \\
\hline
\end{tabular}

*not significant 
The amount of biomass in individual harvests, as an average for treatments, was the largest in the first one (4.04 and $4.30 \mathrm{Mg} \mathrm{ha}^{-1}$ ), but the smallest in the third (3.26 and $3.22 \mathrm{Mg} \mathrm{ha}^{-1}$ ). The biomass yield (average for years) was significantly higher only on the plot where slurry was supplemented with mineral NPK (12.65 $\mathrm{Mg} \mathrm{ha}^{-1}$ ) than in plants where slurry was applied on its own $\left(11.90 \mathrm{Mg} \mathrm{ha}^{-1}\right)$.

The total protein content in grass dry matter (Table 4) was significantly differentiated across treatments and growing seasons. The largest average protein content was in plants treated with slurry supplemented with mineral NPK; in the first year it was $162.8 \mathrm{~g} \mathrm{~kg}^{-1} \mathrm{DM}$, in the second $163.4 \mathrm{~g} \mathrm{~kg}^{-1} \mathrm{DM}$. The smallest average protein content of Lolium multiflorum was recorded on control: $128.4 \mathrm{~g} \mathrm{~kg}^{-1}$ in the first and $129.4 \mathrm{~g} \mathrm{~kg}^{-1}$ in the second year of the experiment.

The addition of soil conditioners to slurry did not have a more favourable effect on protein content than the effect of slurry applied on its own. The mean protein content in plants treated with soil conditioners and slurry was lower than on plots treated with slurry only. Mean (across years and treatments) protein content decreased in consecutive harvests, and it was the largest in the first $\left(155.4 \mathrm{~g} \mathrm{~kg}^{-1}\right)$ and the smallest in the third $\left(145.9 \mathrm{~g} \mathrm{~kg}^{-1}\right)$.

Table 4. Protein concentration in Lolium multiflorum dry matter $\left({\left.\mathrm{g} \mathrm{g}^{-1}\right)}^{-1}\right.$

\begin{tabular}{|c|c|c|c|c|c|c|c|}
\hline \multirow{2}{*}{$\begin{array}{c}\text { Growing } \\
\text { season } \\
\text { (B) }\end{array}$} & \multirow{2}{*}{$\begin{array}{l}\text { Harvest } \\
\text { (C) }\end{array}$} & \multicolumn{5}{|c|}{ Treatments (A) } & \multirow{2}{*}{ Means } \\
\hline & & $\mathbf{O}$ & $\mathbf{S}$ & S + UGmax & $\mathbf{S}+\mathbf{H A}$ & $\mathrm{S}+\mathrm{NPK}$ & \\
\hline \multirow{4}{*}{2016} & $\mathrm{I}$ & 135.6 & 167.1 & 153.8 & 152.5 & 163.9 & 154.6 \\
\hline & II & 123.8 & 156.3 & 162.5 & 158.7 & 169.5 & 154.2 \\
\hline & III & 125.7 & 149.8 & 136.9 & 146.8 & 154.9 & 142.8 \\
\hline & Means & 128.4 & 157.7 & 151.1 & 152.7 & 162.8 & 150.5 \\
\hline \multirow{4}{*}{2017} & I & 132.5 & 168.2 & 160.1 & 168.7 & 168.1 & 159.5 \\
\hline & II & 130.4 & 159.4 & 148.4 & 151.4 & 164.6 & 150.8 \\
\hline & III & 125.4 & 158.6 & 159.2 & 154.9 & 157.6 & 151.1 \\
\hline & Means & 129.4 & 162.1 & 155.9 & 158.3 & 163.4 & 153.6 \\
\hline \multicolumn{2}{|c|}{$\begin{array}{c}\text { Means across growing } \\
\text { seasons } \\
\end{array}$} & 128.9 & 159.9 & 153.5 & 155.5 & 163.1 & 152.1 \\
\hline \multicolumn{8}{|c|}{ Means across harvests } \\
\hline \multicolumn{2}{|c|}{ I } & 134.1 & 167.4 & 167.0 & 160.1 & 166.0 & 158.9 \\
\hline \multicolumn{2}{|c|}{ II } & 127.1 & 157.9 & 155.5 & 155.1 & 167.1 & 152.5 \\
\hline \multicolumn{2}{|c|}{ III } & 125.6 & 154.2 & 148.1 & 150.9 & 156.3 & 147.0 \\
\hline $\mathrm{LSD}_{0.05}$ for: & $\begin{array}{l}\mathrm{A}=9.4 \\
\mathrm{~A} / \mathrm{B}=\mathrm{N} \\
\mathrm{C} / \mathrm{A}=\mathrm{N}\end{array}$ & & $\begin{array}{l}19 \\
=\mathrm{NS} \\
\mathrm{NS} \\
\end{array}$ & $\begin{array}{l}\mathrm{C}=\mathrm{NS} \\
\mathrm{A} / \mathrm{C}=\mathrm{NS} \\
\mathrm{C} / \mathrm{B}=\mathrm{NS}\end{array}$ & & & \\
\hline
\end{tabular}

Another ingredient in assessing feed quality is crude ash. Crude ash content in Lolium multiflorum dry matter (Table 5) significantly varied in both years. In the first year of research, the largest accumulation of crude ash $\left(107.3 \mathrm{~g} \mathrm{~kg}^{-1}\right)$ was recorded in the biomass of the grass treated with slurry only. In the second year, on average, the most crude ash was on plots with slurry and mineral fertilizers $\left(119.5 \mathrm{~g} \mathrm{~kg}^{-1}\right)$.

The smallest crude ash content in the first year of research was in plants treated with slurry and NPK $\left(102.3 \mathrm{~g} \mathrm{~kg}^{-1}\right)$, and in the second on the control plot $\left(102.7 \mathrm{~g} \mathrm{~kg}^{-1}\right)$. 
Across harvests, in the first year the largest ash content was recorded in the biomass of the third one $\left(113.3 \mathrm{~g} \mathrm{~kg}^{-1}\right)$ and in the second one $\left(114.4 \mathrm{~g} \mathrm{~kg}^{-1}\right)$, with the lowest amount in the first harvest of the first year $(97.3 \mathrm{~g} \mathrm{~kg})$ and in third one in the second year $(107.9 \mathrm{~g} \mathrm{~kg})$. Crude ash content, the average of years and harvests, was the smallest on the control plot $\left(103.6 \mathrm{~g} \mathrm{~kg}^{-1}\right)$ and the largest in plants treated with slurry and mineral fertilizers $\left(110.9 \mathrm{~g} \mathrm{~kg}^{-1}\right)$.

Table 5. Crude ash concentration in Lolium multiflorum dry matter $\left({\left.\mathrm{g} \mathrm{g}^{-1}\right)}^{-1}\right.$

\begin{tabular}{|c|c|c|c|c|c|c|c|}
\hline \multirow{2}{*}{$\begin{array}{l}\text { Growing } \\
\text { season } \\
\text { (B) }\end{array}$} & \multirow{2}{*}{$\begin{array}{l}\text { Harvest } \\
\text { (C) }\end{array}$} & \multicolumn{5}{|c|}{ Treatments (A) } & \multirow{2}{*}{ Means } \\
\hline & & $\mathbf{O}$ & $\mathbf{S}$ & S + UGmax & $\mathbf{S}+\mathbf{H A}$ & S + NPK & \\
\hline \multirow{4}{*}{2016} & $\mathrm{I}$ & 97.6 & 95.5 & 98.9 & 92.3 & 102.3 & 97.3 \\
\hline & II & 103.7 & 102.6 & 99.7 & 105.6 & 99.9 & 102.3 \\
\hline & III & 112.1 & 123.9 & 111.6 & 114.5 & 104.6 & 113.3 \\
\hline & Means & 104.5 & 107.3 & 103.4 & 104.1 & 102.3 & 104.3 \\
\hline \multirow{4}{*}{2017} & $\mathrm{I}$ & 89.5 & 110.1 & 119.8 & 115.6 & 129.4 & 112.9 \\
\hline & II & 103.5 & 116.8 & 115.7 & 116.2 & 119.7 & 114.4 \\
\hline & III & 115.0 & 110.8 & 100.6 & 103.8 & 109.3 & 107.9 \\
\hline & Means & 102.7 & 112.6 & 112.0 & 111.9 & 119.5 & 111.7 \\
\hline \multicolumn{2}{|c|}{$\begin{array}{l}\text { Means across growing } \\
\text { seasons }\end{array}$} & 103.6 & 109.9 & 107.7 & 108.0 & 110.9 & 108.0 \\
\hline \multicolumn{8}{|c|}{ Means across harvests } \\
\hline \multicolumn{2}{|c|}{ I } & 93.6 & 102.8 & 109.4 & 103.9 & 115.9 & 105.1 \\
\hline \multicolumn{2}{|c|}{ II } & 103.6 & 109.7 & 107.7 & 110.9 & 109.8 & 108.3 \\
\hline \multicolumn{2}{|c|}{ III } & 113.6 & 117.4 & 106.1 & 109.2 & 106.9 & 110.6 \\
\hline $\mathrm{LSD}_{0.05}$ for: & $\begin{array}{l}\mathrm{A}=\mathrm{NS} \\
\mathrm{A} / \mathrm{B}=\mathrm{N} \\
\mathrm{C} / \mathrm{A}=\mathrm{N}\end{array}$ & & $\begin{array}{l}02 \\
\text { NS } \\
9.94\end{array}$ & $\begin{array}{l}\mathrm{C}=\mathrm{NS} \\
\mathrm{A} / \mathrm{C}=\mathrm{NS} \\
\mathrm{C} / \mathrm{B}=12.3\end{array}$ & & & \\
\hline
\end{tabular}

\section{Discussion}

Due to the fact that Lolium multiflorum is a short-term grass it can be used for alternating grassland. Studies have shown that its yields ranges from 9.10 to $12.65 \mathrm{Mg}$ $\mathrm{ha}^{-1}$. According to Jankowski et al. (2008) Lolium multiflorum is a high-productivity species. This is also confirmed by the study of Borowiecki (2002a, b), according to who the Lolium multiflorum yield can range from 9 to $12 \mathrm{Mg} \mathrm{ha}^{-1}$.

In the present studies the best results in the form of increased biomass of the grass (an average across years and harvests) were recorded on plots where slurry was supplemented with mineral fertilizers. Olszewska (2008) points out that the yield is the basic criterion for assessing treatment effectiveness. A yield increase as a response to natural fertilizer applied to grassland was also recorded by Barszczewski et al. (2011). The present studies showed that slurry supplemented with soil conditioners increased the amount of biomass of the grass, and it was 16-20\% greater than on the control plot, while slurry supplement with NPK fertilizers increased the yield by $40 \%$.

According to Kryszak et al. (2012) as well as Jankowska-Huflejt (2012) periodic shortage of water reduces the yield of meadow plants below their potential. 
In the first year (2016) the optimum thermal and humidity conditions were only in the month of September, with severely wet May, while June, July and August, which are the most significant months for the growth and development of plants, were dry, moderately dry, and extremely dry. In the second year of the experiment (2017), the period from May to August ranged from dry to very dry, and the optimum conditions were not recorded during any month of the growing season.

The optimum total protein content is very important from the point of view of grass nutritional value. According to Grygierzec (2012) the lowest protein content in forage, necessary for the proper digestion process, should ranged from 150 to $170 \mathrm{~g} \mathrm{~kg}^{-1} \mathrm{DM}$. In contrast, according to Jankowska-Huflejt et al. (2011), Lolium multiflorum biomass should contain about $115 \mathrm{~g} \mathrm{~kg}^{-1} \mathrm{DM}$. In the present experiment protein content was within the limits of 128.9 to $163.1 \mathrm{~g} \mathrm{~kg}^{-1} \mathrm{DM}$, and it was undoubtedly the nitrogen introduced in the form of slurry and mineral fertilizer that increased it.

Kotlarz et al. (2010) as well as Kasperczyk (2004) confirm that the level of nitrogen fertilizer determines total protein content in forage. Many authors (Ciepiela, 2004; Jankowska et al., 2008; Szkutnik et al., 2012) point out that total protein content is not always increased in proportion to the applied nitrogen fertilizer. A lower total protein content in dry matter may be due to the high yield potential of the species and it can be caused by dilution of the content of this ingredient in the higher amount of biomass.

In the present experiment protein content in biomass depends on the harvest from which it originates. The dependence of the harvest impact on total protein content in grass was confirmed in the studies of Łyszczarz (2003) and Tonn et al. (2013). According to Juszczyk and Rękorajski (2007) the components of crude ash are chemical elements whose adequate quantity in forage is necessary for the normal growth and development of animal organisms, while excessive content (above $150 \mathrm{~g} \mathrm{~kg}^{-1} \mathrm{DM}$ ) may result from contamination of plant material with soil (Nazaruk et al., 2009).

Throughout the research crude ash content in Lolium multiflorum ranged from 89.5 $\mathrm{g} \cdot \mathrm{kg}^{-1}$ to $123.9 \mathrm{~g} \mathrm{~kg}^{-1}$ and did not exceed the above value, which shows the purity of the plant material analysed. Kotlarz et al. (2010) and Grzelak and Bocian (2009) point out that low content of crude ash of $40 \mathrm{~g} \mathrm{~kg}^{-1} \mathrm{DM}$ in the forage may be related to low concentration of minerals in the soil and to species composition of the forage.

In the present experiment, the analysis of the content of this parameter clearly showed a significant effect of slurry application in comparison with the control plot. An increase in crude ash in meadow forage as a result of natural fertiliser application was also noted by Jankowska-Huflejt and Wróbel (2010); Barszczewski et al. (2010) as well as Wróbel et al. (2013).

In the present experiment in the first year crude ash content in Lolium perenne increased in subsequent harvests (from 97.3 to $113.3 \mathrm{~g} \mathrm{~kg}^{-1}$ ). In the second year a reverse trend was recorded. Barszczewski et al. (2010) found that ash content in meadow plants varied depending on harvest time.

The obtained test results clearly show that the supplementary use of biopreparations did not affect the increase of the grass grown or the protein content in it compared to the facilities where the slurry itself was used. Only the addition to the slurry of mineral fertilization improved the value of these parameters in relation to the operation of the slurry itself. 


\section{Conclusions}

1. The dry matter yield of Lolium multiflorum significant varied across treatments and harvests. In both years of the research the highest yield of the grass was on the plot treated with slurry and mineral fertilizers, and the interaction of slurry with soil conditioners resulted in a decrease in the yield compared to the slurryonly plot.

2. Total protein content in Lolium multiflorum forage was significantly dependent on the treatment and growing season. The largest total protein content was recorded in biomass from the plot where slurry was applied together with mineral fertilizers, but this was not significantly different from plants treated with slurry only.

3. The growing season had a significant impact on crude ash content in the grass. The greatest amount of ash (on average from growing seasons and treatments) was recorded in Lolium multiflorum of the third harvest, while the least crude ash in the first one.

4. The obtained research results showed a beneficial effect of the slurry interaction only with mineral fertilization, while the interaction with biopreparations did not bring the expected effects. The most likely cause could be adverse hydrothermal conditions in both growing seasons of the crop. Therefore, the assessment of the interaction of slurry with biopreparations requires further research.

\section{REFERENCES}

[1] Bac, S., Koźmiński, C., Rojek, M. (1993): Agrometeorology. - State Publishing House, Warsaw, pp. 32-33 (in Polish).

[2] Barszczewski, J., Wróbel, B., Jankowska-Huflejt, H. (2011): Economic effect of permanent meadow spreading with the meadow limb. - Water - Environment - Rural Areas 3(35): 21-37 (in Polish).

[3] Barszczewski, J., Wróbel, B., Jankowska-Huflejt, H., Mendra, M. (2010): Impact of various fertilization methods on meadow sward and the quality of silage obtained. Scientific Notebooks of the College of Agribusiness in Łomża 46: 7-16 (in Polish).

[4] Borowiecki, J. (2002a): Productivity of papilionaceous plants and their mixtures with grasses. - Puławski Diary 130/I: 57-63 (in Polish).

[5] Borowiecki, J. (2002b): Yielding of Festulolium cultivar Felopa in single-species sowing and mixtures with cocksfoot. - Puławski Diary 131: 49-58 (in Polish).

[6] Brzóska, F., Śliwiński, B. (2011): Quality of roughage for feeding ruminants and methods of its assessment. Vol. II. Methods for analyzing and assessing the nutritional value of roughage. - Zootechnical News XLIX(4): 57-68 (in Polish).

[7] Burns, G. A., Gilliland, T. J., McGilloway, D. A., O'donovan, M., Lewis, E., Blount, N., O'Kely, P. (2010): Using LSDS to predict composition characteristics of Lolium perenne L. cultivars. - Advances in Animal Biosciences 1: 321-321.

[8] Ciepiela, A. G. (2004): Reaction of Selected Grass Species to Nitrogen Fertilization Used in Urea Solution and in Ammonium Nitrate. - Scientific Dissertation No. 76. AP, Siedlce (in Polish).

[9] Falkowski, M., Kukułka, I., Kozłowski, S. (2000): Chemical Properties of Meadow Plants. - UP, Poznań (in Polish). 
[10] Grygierzec, B. (2012): Content of basic nutrients and fiber fractions in hay from extensively used communities of Alopecuretum pratensis and Holcetum lanati. Grassland in Poland 15: 53-65 (in Polish).

[11] Grzelak, M., Bocian, T. (2009): Nutritional value of green fodder and hay from ecological meadows. - Journal of Research and Applications in Agricultural 54(3): 8690.

[12] Jankowska, J., Ciepiela, A. G., Kolczarek, R., Jankowski, K. (2008): Impact of the type of mineral fertilizer and nitrogen dose on yield and nutritional value of permanent meadow sward. - Puławski Diary 147: 125-138 (in Polish).

[13] Jankowska-Huflejt, H. (2012): Durability and forage value of grass mixtures and their varieties as well as small-seeded papilionaceous plants selected for mowing use in organic farming. - Journal of Research and Applications in Agricultural 57(3): 172-178 (in Polish).

[14] Jankowska-Huflejt, H., Wróbel, B. (2010): Assessment of the impact of manure fertilization on the nutritional value of meadow sward and its suitability for ensiling. Institute of Technology and Life Sciences in Falenty 133-136 (in Polish).

[15] Jankowska-Huflejt, H., Wróbel, B., Barszczewski, J., Domański, P. J. (2011): Mowing Use of Meadows on Organic Farms. - In: Węglarzy, K., Czubała, A. (eds.) Guide of the Organic Farmer. Śląski, Grodziec, pp. 70-110 (in Polish).

[16] Jankowski, K., Jodełka, J., Ciepiela, G. A., Kolczarek, R. (2008): Grasslands. - AP, Siedlce, pp. 32-35 (in Polish).

[17] Juszczyk, S., Rękorajski, M. (2007): Direct costs of meadow and grazing feed on dairy farms of the Łódź province. - Annals of Agricultural Sciences 94(2): 35-45.

[18] Kasperczyk, M. (2004: Yielding of mountain meadow depending on the course of meteorological conditions. - Acta Agrophysica 3(2): 263-269 (in Polish).

[19] Kitczak, T., Malinowski, R., Czyż, H. (2011): Content of macro- and microelements in soils and sward of grassland located on the Wrzosowska Bay. - Grassland in Poland 14: 51-61 (in Polish).

[20] Kotlarz, A., Stankiewicz, S., Biel, W. (2010): Botanical and chemical composition of hay from a semi-natural meadow and its nutritional value for horses. - Acta Sci. Pol., Zootechnica 9(4): 119-128 (in Polish).

[21] Kryszak, A., Klarzyńska, A., Kryszak, J., Strychalska, A., Maćkowiak, Ł. (2012): Influence of variability of ryegrass meadow soil conditions on their natural and utilization values. - Not. Bot. Horti. Agrobo. 40(1): 163-169.

[22] Kukułka, J., Kozłowski, S. (2004): Chemical Properties of Meadow Plants. - In: Rogalski, M. (ed.) Grassland. Kurpisz, Poznań, pp. 80-111.

[23] Łyszczarz, R. (2003): Impact of the harvest date on selected features of two varieties of cocksfoot. - Bulletin of the Institute of Plant Breeding and Acclimatization 225: 139-149.

[24] Nazaruk, M., Jankowska-Huflejt, H., Wróbel, B. (2009): Evaluation of feed nutritional value from permanent pasture on the ecological farms studied. - Water - Environment Rural Areas 1(25): 61-76 (in Polish).

[25] Olszewska, M. (2008): Leaf greenness (SPAD) and yield of Festulolium braunia (K. Richt.) A. Camus grown in mixtures with legumes depending on multiple nitrogen rates. - Polish Journal of Natural Sciences 23(2): 310-325.

[26] Reddersen, B., Fricke, T., Wachendorf, M. (2012): Influence of LSDS - method on the calibration of N-, ash- and NDF-content of grassland hay and silage. Grassland - a European Resource? - EGF, Grassland Sciences in Europe 17: 385-387.

[27] Skowera, B., Puła, J. (2004): Extreme pluvirothermic conditions in spring in Poland in 1971-2000. - Acta Agrophysica 3(1): 171-177 (in Polish).

[28] Systematics of Polish Soils (2011): Polish soil classification. - Annals of Soil Science 62(3) (in Polish). 


$$
\text { - } 2268 \text { - }
$$

[29] Szkutnik, J., Kacorzyk, P., Szewczyk, W. (2012): Change in total protein content and raw fiber depending on the level of fertilization and the development phase of grasses. Grassland in Poland 15: 185-191 (in Polish).

[30] Tonn, B., Bienvenu, C., Isselstein, J. (2013): Assessing quantity and quality of grazed forage on multi-species swards. The role of grasslands in a green future. - EGF, Grassland Sciences in Europe 18: 82-84.

[31] Wróbel, B., Zielińska, K. J., Fabiszewska, A. U. (2013): Impact of bovine manure fertilization on the quality of sward and its suitability for ensilage. - Problems of Agricultural Engineering 2(80): 151-164 (in Polish). 